\title{
A Retrospective Case Series of Minimally Invasive Ponto Surgery In Two Pediatric Centres
}

\author{
Gabrielle French ${ }^{1}$, Kenneth Lee $^{2}$, and Warren Yunker ${ }^{3}$ \\ ${ }^{1}$ University of Calgary Cumming School of Medicine \\ ${ }^{2}$ University of Texas, Southwestern Medical Center, Tx, USA \\ ${ }^{3}$ University of Calgary
}

October 1, 2020

\begin{abstract}
Objective: Minimally Invasive Ponto Surgery (MIPS) is a type of bone anchored hearing system performed through a puncture hole that has been reported to minimize soft tissue trauma, decrease operative time, and have favorable outcomes. Due to it being a relatively new procedure there remains a paucity of pediatric outcomes data. Our objective was to study MIPS outcomes in the pediatric population. Design: Retrospective review. Setting: The study was performed at two tertiary pediatric otolaryngology centres between 2016-2019. Participants: Pediatric patients from two tertiary pediatric otolaryngology clinics who underwent MIPS between 2016-2019. Main Outcome Measures: Outcomes included indication for surgery, implant and abutment type, overlying skin thickness, skin-to-skin time, Holgers score at three, six and twelve months, revision surgery and time to abutment fitting. Results and Conclusions: Fourteen patients, two with bilateral procedures met inclusion criteria (mean age $=8.07 \pm 2.87$ years). The main etiology for the hearing loss was microtia $(64 \%)$. The mean overlying skin thickness was $5.13 \pm 3.18 \mathrm{~mm}$. Across all visits, $9.44 \%$ had Holger's scores $>2$, which is classified as an adverse skin reaction. One of these patients required surgery to address skin overgrowth. One implant loss (6.3\%) was reported, but found to be in the setting of trauma. Mean MIPS Skin to skin times were found to be $12.4 \pm 2.6$ minutes, markedly different that the Bahaß Attract and Connect found to be 56 and 53 minutes respectively. This study represents the largest pediatric MIPS cohort to date, and our results are similar to published adult studies.
\end{abstract}

\section{Hosted file}

A Retrospective Evaluation of MIPS Manuscript.pdf available at https://authorea.com/users/ 363536/articles/484272-a-retrospective-case-series-of-minimally-invasive-ponto-surgeryin-two-pediatric-centres

Hosted file

Table 1 MIPS.pdf available at https://authorea.com/users/363536/articles/484272-aretrospective-case-series-of-minimally-invasive-ponto-surgery-in-two-pediatric-centres

Hosted file

Table 2 MIPS.pdf available at https://authorea.com/users/363536/articles/484272-aretrospective-case-series-of-minimally-invasive-ponto-surgery-in-two-pediatric-centres

\section{Hosted file}

Figure 1 MIPS.pdf available at https://authorea.com/users/363536/articles/484272-aretrospective-case-series-of-minimally-invasive-ponto-surgery-in-two-pediatric-centres 